\title{
Regional Committee decisions
}

The World Health Organization (WHO) Regional Committee for the Eastern Mediterranean is WHO's decision-making body in the Eastern Mediterranean Region. It meets annually with representation from all Member States of the Region. A main function of the Committee is to formulate policies and strategies that provide Member States with guidance on action that needs to be taken to promote and protect health in the Region. This section, Regional Committee Decisions, serves to highlight selected resolutions and decisions of the Committee to inform and update readers of the key actions related to the regional health priorities to be undertaken by countries and WHO.

\section{Regional health and environment strategy and framework for action in the Eastern Mediterranean Region, 2014-2019}

\section{Introduction}

The sixtieth session of the World Health Organization (WHO) Regional Committee for the Eastern Mediterranean endorsed (in October 2013) a new regional strategy on health and the environment with a framework for action during 2014-2019 (1). The strategy provides a roadmap for protecting health from environmental risks in the Eastern Mediterranean Region (EMR). This paper summarizes the key themes, including pertinent environmental health pressures, states and responses described in the strategy.

Environmental determinants of health are responsible for about $24 \%$ of the burden of disease, leading to more than 1 million deaths and 38 million disability-adjusted life years (DALYs) lost each year in the EMR (2). In economic terms, this DALYs loss can be translated into an estimated annual loss of US\$ 144 billion (based on a very conservative assumption, this equals the gross domestic product of Member States in the Region for one year). Despite the variable impacts and differing health consequences, all countries are adversely affected by the risks of environmental pollution and ecological deterioration. Such risks are aggravated by the onset of climate change and unsustainable development.

The enormity of the environment-related burden of disease means that these exposures and related health risks cannot be addressed effectively if they are addressed separately. It is essential to adopt an integrated ecological public health approach which recognizes the complex interactions between biological, behavioural, environmental and social factors. For such a multisectoral approach to work, the role and mandate of ministries of health and other government sectors need to be revisited.
The evidence linking environmental risks with communicable diseases is well established historically. Action to tackle these factors is cost-effective and can result in major reductions in morbidity and mortality associated with waterborne, foodborne, and vector-borne diseases. Evidence linking environmental risks to noncommunicable diseases and injuries is also emerging rapidly. For example, $19 \%$ of all cancers (3) and 16\% of all cardiovascular diseases (4) have been attributable to the environment. Action to manage these risks is cost-effective and can result in major reductions in the burden of disease associated with air pollution, chemical toxins, radiation, hazardous wastes and traffic accidents

The priorities and strategic directions set out in the EMR regional strategy on health and the environment are based on the magnitude of the problem, the current scientific evidence and justification for suggested interventions, the expressed demand from countries for appropriate interventions, and the binding international and regional framework agreements already in place. Rigorous review of evidence and expert consensus were employed systematically in developing the strategy. It takes into account and is aligned with the priorities identified by countries in the WHO Country Cooperation Strategy (5), as well as the recommendations of two regional consultations, held in June 2011 and November 2012.

\section{Strategic framework}

Many aspects of environmental health services are outside the mandate of a single agency. Therefore, it is essential that a collaborative multi-agency approach is adopted, emphasizing the leadership of the health sector in terms of governance and surveillance responsibilities, as well as advocacy and 


\begin{tabular}{|c|c|c|c|c|c|c|c|}
\hline Country & $\begin{array}{c}\text { Deaths per } \\
100000\end{array}$ & Country & $\begin{array}{l}\text { Deaths per } \\
100000\end{array}$ & Country & $\begin{array}{l}\text { Deaths per } \\
100000\end{array}$ & Country & $\begin{array}{c}\text { Deaths per } \\
100000\end{array}$ \\
\hline Afghanistan & 748 & Pakistan & 196 & Morocco & 106 & Bahrain & 58 \\
\hline Somalia & 603 & Lebanon & 132 & Saudi Arabia & 91 & Oman & 55 \\
\hline Iraq & 316 & Tunisia & 124 & Libya & 85 & Kuwait & 33 \\
\hline Sudan & 256 & Egypt & 117 & Jordan & 83 & UAE & 33 \\
\hline Djibouti & 255 & $\begin{array}{l}\text { Islamic } \\
\text { Republic of Iran }\end{array}$ & 113 & $\begin{array}{l}\text { Syrian Arab } \\
\text { Republic }\end{array}$ & 72 & Qatar & 32 \\
\hline Yemen & 247 & & & & & & \\
\hline
\end{tabular}

Source: Data extracted from the WHO Global Burden of Disease, 2008 update.

motivation of other specialized environmental health service agencies. Keeping this in mind, the new strategy guides $\mathrm{WHO}$ and countries of the EMR to adopt the following strategic directions:

- enhancing the capacity of the health sector to evaluate, monitor, regulate and manage environmental risks;

- strengthening the advocacy, partnership building and leadership roles of the health sector for mobilizing resources and synergizing actions of pertinent sectors and providers of environmental health services;

- equipping the health sector with environmental norms and assessment tools for catalysing stakeholders to integrate health protection measures into their development processes.

\section{Environmental health situation in the EMR}

The countries of the EMR differ greatly in terms of their socioeconomic, demographic, environmental and health conditions. Tables 1 and 2 provide a good example of this diversity in terms of environmental impacts. Three groups of countries can be defined. Group 1 including high-income countries with good environmental health services; group 2 includes middle-income countries with "endeavouring" environmental health services; and group
3 countries include low-income countries with poor and lacking environmental health services. While the health impacts of environmental deterioration are mostly manifested in high communicable disease prevalence in group 3 countries, a clear transition in the impact of environmental risks is depicted in group 1 and 2 countries, where environmental deterioration is shifting in trend from affecting communicable disease to affecting noncommunicable disease prevalence.

\section{Key environmental health priorities in EMR}

In light of the burden of disease analysis, the country cooperation strategies and the expressed needs of countries, seven technical areas of work are recommended as priorities in the strategy. These areas are: water and sanitation, air quality, chemical safety, waste management, emergencies, climate change and sustainable development. The following sections describe the overall situation of these priorities in the EMR, and the recommended strategic actions by WHO and countries of the Region.

\section{Water and sanitation}

Domestic water availability has declined steadily as a result of water scarcity and is aggravated by climate change and population growth. Many water supply systems in the EMR

\begin{tabular}{|c|c|c|c|}
\hline Variable & Group 1 & Group 2 & Group 3 \\
\hline Income group & High & Middle & Low \\
\hline $\begin{array}{l}\text { Level of environmental health } \\
\text { services }\end{array}$ & Good & Endeavouring & Lacking \\
\hline EMR population (\%) & 7 & 44 & 49 \\
\hline $\begin{array}{l}\text { Burden of disease } \\
\text { (DALYs per } 1000 \text { capita per year) }\end{array}$ & 25.4 & 39.3 & 94.4 \\
\hline Priority environmental risk factors & $\begin{array}{l}\text { Air pollution } \\
\text { Injury risk factors } \\
\text { Chemicals }\end{array}$ & $\begin{array}{l}\text { Water and sanitation } \\
\text { Air pollution } \\
\text { Chemicals and wastes }\end{array}$ & $\begin{array}{l}\text { Water and sanitation } \\
\text { Indoor air pollution } \\
\text { Chemicals and wastes }\end{array}$ \\
\hline
\end{tabular}

$D A L Y_{S}=$ disability-adjusted life years. 


\begin{tabular}{|c|c|c|}
\hline \multirow[t]{2}{*}{ Country } & \multicolumn{2}{|c|}{ \% with access to: } \\
\hline & Water & Sanitation \\
\hline Afghanistan & 39 & 72 \\
\hline Djibouti & 8 & 39 \\
\hline Iraq & 15 & 16 \\
\hline Morocco & 18 & 30 \\
\hline Pakistan & 9 & 53 \\
\hline Somalia & 70 & 76 \\
\hline Sudan & 45 & 76 \\
\hline Yemen & 45 & 47 \\
\hline
\end{tabular}

Source: WHO/UNICEF Progress on sanitation and drinking-water: 2013 update (6).

experience interruptions, exposing the population to health threats due to lack of water safety safeguards. The 2012 WHO/UNICEF Joint Monitoring Programme on the Water and Sanitation Sector indicated that all group 3 countries and some countries in group 2 are not on track to achieve the targets of Millennium Development Goal 7 relating to water and sanitation (6). Of the populations of countries listed in Table 3 , between $8 \%$ and $70 \%$ remain without improved access to water and between $16 \%$ and $76 \%$ without improved access to sanitation.

In response to this chronic challenge, the strategy proposes action by WHO and countries of the EMR to: monitor the performance of the health outcomes of the water and sanitation sector; generate evidence-based guidance and health-based targets; strengthen the regulatory and surveillance roles of the health sector pertinent to the water and sanitation systems; and strengthen the capacity to conduct strategic reviews, delineation and operationalization of best policies and programme options in the areas of water and wastewater quality and safety.

\section{Air quality}

WHO estimates that in each year, indoor and outdoor air pollution kill about 145000 and 117000 people respectively in the EMR (7). Most of the deaths due to indoor pollution occur in group 3 countries, where about 170 million people still burn solid fuels for cooking and heating (based on data extracted from the Global Health Observatory on the percentage of populations burning solid fuels in 2010) (Table 4). While further research is needed to investigate the magnitude of the problem, recent reports have revealed that, because of increases in clean fuel prices, the use of dirty fuels for cooking and heating is increasing. The major sources of indoor air pollution in group 2 and 3 countries are environmental tobacco smoke, building materials and heating practices. Unlike indoor air pollution, outdoor air pollutants have impact on all three groups of countries. The major sources of outdoor air pollution in the EMR are traffic and industrial air emissions, and sand and dust storms, which are aggravated by climate change. Recent estimates published by the Institute for Health Metrics and Evaluation in 2012 indicate that the health impact of air pollution is much larger than the current estimates suggest (8).

The strategy calls for action by $\mathrm{WHO}$ and countries to: strengthen the regulatory capacity and partnership building roles of the health sector for establishing and monitoring national air quality standards in line with WHO air quality norms; develop/strengthen the surveillance function of the health sector with regard to air quality; and increase the awareness of all stakeholders (including the public) about air pollution risks.

\section{Chemical safety}

Based on the few chemicals for which data are available an estimated $8.3 \%$ of global deaths and $5.7 \%$ of global DALYs are attributable to exposure to chemicals (9). This is likely to be an underestimate of the actual burden and includes estimates from the following sources: chemicals involved

\begin{tabular}{|c|c|c|}
\hline \multicolumn{3}{|c|}{$\begin{array}{l}\text { Table } 4 \text { Deaths attributable to air pollution per } 100000 \\
\text { population in the countries of the Eastern Mediterranean } \\
\text { Region }\end{array}$} \\
\hline \multirow[t]{2}{*}{ Country } & \multicolumn{2}{|c|}{ Deaths per 100000} \\
\hline & $\begin{array}{l}\text { Indoor } \\
\text { pollution }\end{array}$ & $\begin{array}{l}\text { Outdoor } \\
\text { pollution }\end{array}$ \\
\hline Afghanistan & 228 & 3.74 \\
\hline Bahrain & 0 & 0.00 \\
\hline Djibouti & 6 & 3.90 \\
\hline Egypt & 1 & 0.25 \\
\hline Iran, Islamic Republic & 0 & 0.49 \\
\hline Iraq & 2 & 1.83 \\
\hline Jordan & 0 & 0.41 \\
\hline Kuwait & 0 & 0.03 \\
\hline Lebanon & 0 & 0.05 \\
\hline Libya & 1 & 0.32 \\
\hline Morocco & 2 & 0.59 \\
\hline Oman & 0 & 0.07 \\
\hline Pakistan & 35 & 2.86 \\
\hline Qatar & 0 & 0.08 \\
\hline Saudi Arabia & 0 & 0.25 \\
\hline Somalia & 139 & 3.53 \\
\hline Sudan & 37 & 1.49 \\
\hline Syrian Arab Republic & 4 & 0.21 \\
\hline Tunisia & 1 & 0.08 \\
\hline UAE & 0 & 0.04 \\
\hline Yemen & 33 & 0.82 \\
\hline
\end{tabular}

Source: WHO Global Health Observatory data repository (11). 
in unintentional acute poisonings; chemicals involved in unintentional occupational poisonings; pesticides involved in self-inflicted injuries; asbestos; occupational lung carcinogens; occupational leukaemogens; occupational particulates; outdoor air pollutants; indoor air pollutants from solid fuel combustion; second-hand smoke; lead; and arsenic in drinking water. Although estimates are not available at the regional level, there is sufficient reason to believe that the same trend is valid for the EMR since production and exposure to chemicals are increasing. It is estimated that production of chemicals in the Region will increase by $40 \%$ in 2020 (9).

Several challenges face the countries of the Region, particularly the low-income countries: lack of public awareness and of a culture of safety with regard to handling chemicals; lack of up-to-date databases and experienced human resources to carry out risk assessment of chemicals; lack of legislative frameworks and enforcement mechanisms; overlapping mandates and responsibilities; and lack of international financial mechanisms for multilateral environmental agreements.

Sound management of chemicals and strengthening of national capacities for management of chemicals to protect health will require major investment, as well as the development of new practical techniques for chemical safety. Several objectives are suggested by the strategy including: integrating sound management of chemicals into national health programmes; developing regional and national integrated health and environment monitoring and surveillance systems for chemicals; expanding and disseminating international assessment of chemical risks to countries of the EMR; and harmonizing the classification and labelling of chemicals.

\section{Waste management}

Only a few countries in EMR, such as the member states of the Gulf Cooperation Council, have already constructed treatment, storage and disposal facilities for hazardous wastes. The majority of countries in the Region lack the technological capacity and financial means to build such sophisticated systems. In the absence of such facilities, and exacerbated by weak regulatory enforcement as well as inadequate regional and international cooperation, wastes of all types will continue to be a serious environmental health challenge in the EMR.

Of special concern to WHO is the safe management and disposal of health-care wastes. Countries of the EMR have recently started to pay adequate attention to the proper management of such waste materials. Group 1 countries have initiated effective health care waste management strategies, group 2 countries mostly meet the minimum requirements for proper management, and group 3 countries have not yet begun to implement adequate management of such waste materials.

Given the diverse mixtures of toxic substances, microbial agents and harmful compounds embedded within waste streams, the risk of adverse health exposures throughout the waste management cycle is very high. The role of national health authorities in the Region must be concentrated on the health aspects of integrated waste management through: strengthening national capabilities and capacities for management of wastes, focusing on the health implications of wastes management; and minimizing health risks associated with exposure to health-care wastes.

\section{Environmental health management in emergencies}

More than half of the countries of EMR are currently suffering from acute or chronic crises. Of the 33 countries that were in health crisis in recent years 13 belong to our Region. Climate change, globalization and rapid urbanization are likely to expose populations to more frequent and complex disasters. The number of refugees and displaced people fleeing complex emergencies in the EMR is increasing. Most of these people are displaced in countries in groups 2 and 3 , which already suffer from weaknesses in their environmental health systems, and many of which are not yet prepared to respond to the additional burden.

A systematic approach to addressing the environmental health aspects of emergencies requires all countries to invest in vulnerability and risk assessment and preparedness. This should include: assessing environmental health risks and vulnerabilities in countries susceptible to crisis improve capacities to effectively manage the environmental health aspects of emergencies; leading the water and sanitation response activities within health-care facilities during emergencies; and protecting health from environmental risks throughout all phases of the disaster/emergency management cycle.

\section{Climate change}

All countries of the EMR are observing environmental changes, among them increases in temperature, heat waves, reductions in rainfall, decline in productivity of crops and in food security, decline in air quality and increases in frequency of dust storms. WHO estimates that the Region is the second most affected in the world after the African Region. The health effects of climate change include: death and injuries due to heat waves and extreme weather events, and changing disease patterns, including increase in waterborne, foodborne and vector-borne diseases, malnutrition, respiratory diseases and asthma. The EMR already faces numerous emergency and humanitarian crises, and climate change is likely to aggravate these situations (10). However, further research is needed to assess the health impact of climatic change in the Region. 


\begin{tabular}{|c|c|c|c|}
\hline Priority & Indicator & $\begin{array}{l}\text { Baseline in } \\
\quad 2014\end{array}$ & $\begin{array}{l}\text { Target in } \\
2019\end{array}$ \\
\hline \multirow[t]{5}{*}{ Water and sanitation } & No. of countries participating in GLAAS & 8 & 15 \\
\hline & No. of countries actively verifying JMP profiles & 15 & 22 \\
\hline & No. of countries with updated drinking water quality standards & 15 & 20 \\
\hline & No. of countries adopting water safety plans & 7 & 12 \\
\hline & No. of countries with updated wastewater reuse standards & 7 & 12 \\
\hline \multirow[t]{3}{*}{ Air quality } & $\begin{array}{l}\text { No. of countries that are reporting particulate matter data to the WHO } \\
\text { Global Database }\end{array}$ & 8 & 15 \\
\hline & No. of studies on burden of air pollution on health & 0 & 6 \\
\hline & No. of countries with ambient air quality early-warning systems & 1 & 3 \\
\hline \multirow[t]{3}{*}{ Waste management } & $\begin{array}{l}\text { No. of countries that assessed environmental health services in their } \\
\text { health-care facilities }\end{array}$ & 6 & 12 \\
\hline & $\begin{array}{l}\text { No. of countries with } 50 \% \text { of health-care facilities meeting WHO } \\
\text { essential standards on environmental health services in health-care } \\
\text { facilities }\end{array}$ & 6 & 12 \\
\hline & $\begin{array}{l}\text { No. of countries that assessed the public health impacts of waste } \\
\text { management policies }\end{array}$ & 0 & 6 \\
\hline \multirow[t]{3}{*}{ Chemical safety } & No. of countries with public health strategies on SAICM & 0 & 5 \\
\hline & $\begin{array}{l}\% \text { of countries with capacity developed to deal with chemical events } \\
\text { under IHR implementation }\end{array}$ & 45 & 85 \\
\hline & $\begin{array}{l}\text { No. of countries covered by functional information poison centre } \\
\text { services }\end{array}$ & 11 & 15 \\
\hline \multirow{3}{*}{$\begin{array}{l}\text { Environmental health } \\
\text { in emergencies }\end{array}$} & No. of countries with environmental health in emergency profiles & 0 & 6 \\
\hline & $\begin{array}{l}\text { Functional network exists for environmental health emergency experts } \\
\text { and institutions ( } \mathrm{no}=0 \text {; yes }=1 \text { ) }\end{array}$ & 0 & 1 \\
\hline & $\begin{array}{l}\% \text { of emergencies adequately responded to with integrated } \\
\text { environmental health services }\end{array}$ & 50 & 90 \\
\hline \multirow[t]{3}{*}{$\begin{array}{l}\text { Climate change and } \\
\text { health }\end{array}$} & $\begin{array}{l}\text { No. of countries with adaptation frameworks on health and climate } \\
\text { change }\end{array}$ & 7 & 13 \\
\hline & $\begin{array}{l}\text { No. of countries with vulnerability assessment and adaptation strategies } \\
\text { on health adaptation to climate change }\end{array}$ & 2 & 7 \\
\hline & $\begin{array}{l}\text { No. of countries incorporating climate data into national health } \\
\text { information systems }\end{array}$ & 1 & 4 \\
\hline \multirow[t]{2}{*}{$\begin{array}{l}\text { Sustainable } \\
\text { development }\end{array}$} & $\begin{array}{l}\text { No. of countries integrating public health in sustainable development } \\
\text { policies as per Rio }+20\end{array}$ & 0 & 3 \\
\hline & No. of countries with programmes on Greening the Health Sector & 0 & 3 \\
\hline
\end{tabular}

GLAAS = Global Analysis and Assessment of Sanitation and Drinking-Water; JMP = WHO/UNICEF Joint Monitoring Programme; SAICM = Strategic Approach to International Chemicals Management; IHR = international health regulations; Rio $+20=$ United Nations Conference on Sustainable Development in Rio de Janeiro, Brazil, 2012.

An integrated multisectoral approach to managing the adverse health effects of climate change is already started through a regional framework for action which was endorsed by the fifty-fifth session of the Regional Committee for the Eastern Mediterranean in 2008. The new strategy calls for continuing action in this direction by: developing health adaptation strategies to climate; building the institutional capacity of the health sector in relation to extreme weather events, and in reinforcing surveillance in the areas of infectious and respiratory diseases, food safety, and nutrition; and establishing early warning systems on climate-sensitive diseases.

\section{Sustainable development and health}

The relationship between health and sustainable development has three main components: improvements in health contribute to the achievement of sustainable development and to poverty reduction; health can be one of the principal outcomes of investment in sustainable development and the green economy; and health indicators provide a powerful 
means of measuring social, economic and environmental progress towards sustainable development.

The strategy calls for: strengthening partnerships and alliances both inside and outside the health sector to address the emerging challenges; positioning health at the centre of sustainable development through measuring and increasing the health gains from development; and promoting health impact assessment for development policies and projects.

\section{Monitoring and evaluation}

Table 5 summarizes the indicators and targets that will be achieved during the life span of the regional strategy on health and the environment.

\section{Conclusions and way forward}

This paper has summarized the recently endorsed regional strategy on health and the environment in EMR, depicting the high burden of environmental risks from communicable and noncommunicable diseases in the Region and, at the same time, the availability of cost-effective environmental health interventions from prevention to mitigation to control.

The new strategy was designed to support countries of the Region in their concerted efforts to reduce the toll of morbidity, disability and premature mortality caused by environmental risks. In order to do so, the ministries of health in the Region will need to assume the roles of stewarding broker and interlocutor in partnership with other actors within their respective governments. It is essential that a collaborative multiagency approach is adopted, emphasizing the leadership role of the health sector in terms of governance and surveillance responsibilities, as well as advocacy and motivation of other specialized environmental health service providers. The strategic actions will be carried out, and indicators monitored and evaluated jointly by the WHO Secretariat (through the results-based biennial workplans) and by countries of the Region.

\section{References}

1. Resolution EM/RC60/R.5. Agenda item 4(a). Regional strategy on health and the environment 2014-2019. In: Sixtieth session of the Regional Committee for the Eastern Mediterranean. October 2013. Cairo: Regional Office for the Eastern Mediterranean; 2013 (http://applications.emro.who.int/ docs/RC60_Resolutions_2013_R5_15138_EN.pdf, accessed 6 February 2014).

2. The global burden of disease: 2004 update. Geneva: World Health Organization; 2008 (http://www.who.int/healthinfo/ global_burden_disease/GBD_report_2004update_full.pdf, accessed 6 February 2014).

3. Environmental and occupational cancers. Fact sheet No. 350. Geneva: World Health Organization; 2011 (http://www.who. int/mediacentre/factsheets/fs350/en/, accessed 6 February 2014).

4. Prüss-Üstün A, Corvalán C. Preventing disease through healthy environments. Towards an estimate of the environmental burden of disease. Geneva: World Health Organization; 2006 (http://www.who.int/quantifying_ehimpacts/ publications/preventingdisease.pdf, accessed 6 February 2014).

5. Country cooperation strategies. Global analysis 2012. Geneva: World Health Organization; 2012.
6. Progress on sanitation and drinking-water: 2013 update. Geneva: World Health Organization and United Nations Children's Fund; 2013 (http://apps.who.int/iris/bitstre am/10665/81245/1/9789241505390_eng.pdf, accessed 6 February 2014).

7. Indoor air pollution. Burden of disease by country. Global health observatory data repository. World Health Organization [online database] (http://apps.who.int/gho/data/node. main-wpro.140?lang=en, accessed 6 February 2014).

8. Country profiles. Institute for Health Metrics and Evaluation [online database] (http://www.healthmetricsandevaluation. org/gbd/country-profiles, accessed 6 February 2014).

9. Prüss-Ustün A, Vickers C, Haefliger P, Bertollini R. Knowns and unknowns on burden of disease due to chemicals: a systematic review. Environ Health: 2011 Jan 21;10:9. doi: 10.1186/1476069X-10-9. PMID: 21255392.

10. Habib RR, Zein KE, Ghanawi J. Climate change and health research in the Eastern Mediterranean Region. Ecohealth. 2010 Jun;7(2):156-75. doi: 10.1007/s10393-010-0330-1. PMID: 20658168

11. Global Health Observatory data repository. World Health Organization [online database] (http://apps.who.int/gho/data/ view.main, accessed 17 February 2014). 